\title{
FREEDOM OF THE ARTS AND SCIENCES AND INTELLECTUAL PROPERTY PROTECTION: AN ITALIAN, EUROPEAN AND INTERNATIONAL LAW PERSPECTIVE
}

DOI: http://dx.doi.org/10.12775/TSP-W.2020.017

Date of receipt: 26.04 .2020

Date of acceptance:15.09.2020

\begin{abstract}
Summary. The study presents the freedom of the arts and sciences and the principles regarding the protection of intellectual property, and it is aimed at analyzing the complex balance between the former and the latter. In order to thoroughly understand this relationship, it is first necessary to clarify what the two elements of this balance are: on the one hand, the freedom of the arts and sciences, which is intimately related to the individual right to access to scientific, artistic and cultural developments, and, on the other, intellectual property regimes. Secondly, it is essential to examine the possible interferences of the protection of one of the two elements under discussion on the other element. Finally, it is fundamental to discuss how different jurisdictions have approached this issue. The whole contribution is conducted in a Comparative and International Law perspective: Italian, European and International Law will be examined. Besides, there will be some interesting hints about the solutions adopted in the US legal system, which are particularly interesting.
\end{abstract}

Keywords: Freedom of the Arts and Sciences, Intellectual Property, Patent, Copyright, Trademark, Balance of Interests. 3890.

${ }^{1}$ Maria Jelda Doria - Università degli Studi di Padova, e-mail: ORCID 0000-0001-6945- 
Wolność sztuki i nauki oraz ochrona własności intelektualnej z perspektywy prawa włoskiego, europejskiego i międzynarodowego - Opracowanie poświęcone zostało probleamtyce wolności sztuki i nauki oraz zasadzie ochrony własności intelektualnej. Ma ono także na celu analizę złożonej równowagi między tą pierwszą a drugą. Aby dogłębnie zrozumieć tę zależność, należy najpierw wyjaśnić, jakie są dwa elementy tej równowagi: z jednej strony wolność sztuki i nauki, która jest ściśle związana z indywidualnym prawem dostępu do naukowych, artystycznych rozwój kulturowy, a z drugiej strony reżimy dotyczące własności intelektualnej. Wreszcie zasadnicze znaczenie ma omówienie, w jaki sposób różne systemy prawne podeszły do tej kwestii. Analiza została przeprowadzona z perspektywy prawa międzynarodowego i porównawczego: omówiono rozwiązania przyjęte w prawie włoskim, europejskim i międzynarodowym. Ponadto scharakteryzowano interesujące rozwiązania przyjęte w systemie prawnym USA.

Słowa kluczowe: wolność sztuki i nauki, własność intelektualna, patenty, prawa autorskie, znak towarowy, równowaga interesów.

\section{THE FUNDAMENTAL RULES ON THE FREEDOM OF THE ARTS AND SCIENCES}

The freedom of the arts and sciences is enshrined in Article 15 paragraph 1 of the International Covenant on Economic, Social and Cultural Rights, which states that everyone has the right "to take part in cultural life" (letter a)) and "to enjoy the benefits of scientific progress and its applications" (letter b)). Moreover, Article 15 par. 3 places upon the States parties to the Covenant an obligation "to respect the freedom indispensable for scientific research and creative activity".

It is worth anticipating that this provision is extremely enlightening for the purpose of this paper: not only does it establish and define the freedom of culture and scientific research, but it also deals with the right of researchers and inventors to benefit from the results of their work.

At this point, it is important to underline that the article under consideration encompasses an individual right to take part in cultural life and to benefit from the achievements of scientific progress, and places an essential value on freedom, which is conceived as necessary for scientific research and creative activity.

The individual right to science and culture is also outlined in Article 27 par. 1 of the Universal Declaration of Human Rights, according to which "everyone has the right freely to participate in the cultural life of the community, to enjoy the arts and to share in scientific advancement and its benefits".

Again, this individual right is linked with the right of inventors to benefit from the results of their work, which is outlined in Article 27 par. 2. 
Coming to European Law, it must me mentioned Article 13 of the Charter of Fundamental Rights of the European Union, which states that "the arts and scientific research shall be free of constraint" and that "academic freedom shall be respected". Moreover - although not perfectly tailored to the topic under consideration - it is opportune to mention Article 9 of the European Convention of Human Rights, that sets forth the individual right to freedom of thought, conscience and religion (par. 1), and deals with the limitations that can legitimately constrain this freedom (according to par. 2, limitations must be prescribed by Law and be necessary in a democratic society in the interests of public safety, for the protection of public order, health or morals, or for the protection of the rights and freedoms of others). It is clear that the focus of this rule is neither the freedom of arts and sciences itself, nor its complex relationship with the inventorship rights that may arise from scientific, artistic and cultural activity. Instead, it focuses on the potential limitation of the above-mentioned freedom.

As far as the Italian Constitution is concerned, it is essential to examine Articles 2, 9 and 33. The first is a milestone provision through which the Republic recognizes and guarantees the inviolable rights of human beings. It can be inferred from the Constitution itself that among these fundamental rights are religious freedom, freedom of thought and scientific, cultural and educational freedom. Accordingly, Article 9 states that the Italian Republic promotes the development of culture and scientific research. Moreover, Article 33 par. 1 enshrines the freedom of arts and sciences, as well as of their teaching. Finally, the last paragraph of article 33 deals with the limits that may be imposed to these freedoms in the specific context of institutions of high culture, universities and academies, stating that these entities have the right to give themselves autonomous regulations within the limits established by the laws of the state.

It should be borne in mind that in Italy there is a strong concern about the limitation of the freedom of scientific research by some state prohibitions inspired by religious beliefs. For instance, with Law 40/2004, the state enters the research laboratories and prohibits carrying out some research ${ }^{2}$.

\section{THE INTELLECTUAL PROPERTY PROTECTION}

An intellectual Property right is the legal tool through which an inventor is provided with the strongest legal protection of their interest to enjoy the fruits

\footnotetext{
2 A. Santosuosso, Proprietà intellettuale e libertà di ricerca scientifica: una relazione complessa, [in:] Ass. Coscioni 13.03.2014, p. 1.
} 
of their inventive activity, that is to say, to be recognized as the inventor and to market and exploit the invention. This result is achieved by depriving any other person of the power on the invention itself, which is clearly an expression of the ius excludendi omnes alios (the power of the landowner to exclude anyone from the land ${ }^{3}$ ), an essential component of the legal category of property ${ }^{4}$. Intellectual property rights are usually divided into three categories: copyright, patents and trademarks ${ }^{5}$.

This paragraph aims to identify the fundamental principles guiding national legislators when enacting intellectual property regimes, and not to thoroughly examine these regimes.

As pointed out by influential Doctrine, the constitutional principles regarding intellectual property present two lines of development: on the one hand, the utilitarian and functionalistic approach, according to which the protection of intellectual property is aimed at enhancing the development of science, art and culture; on the other hand, the naturalistic approach, which links the protection of intellectual property rights to the necessary remuneration for the creator's personal work 6 .

The first approach is found in Article 1 section 8 of the Constitution of the United States of America, according to which the Congress shall have power "to promote the Progress of Science and useful Arts, by securing for limited Times to Authors and Inventors the exclusive Right to their respective Writings and Discoveries".

The second is found in Article 15 of the International Covenant on Economic, Social and Cultural Rights: alongside the freedom of scientific research, it recognizes the fundamental right of the individual "to benefit from the protection of the moral and material interests resulting from any scientific, literary or artistic production of which he is the author" (par. 1 letter c). This provision is extremely valuable in that, besides recognizing the right to protection of the material interests deriving from the scientific or artistic work, it ensures the protection of the moral interests that derive altogether. Indeed, this shows that intellectual property protection has a noble internal core that consists of the recognition of authorship, which comes before economic exploitation.

Similarly, Article 27 par. 2 of the Universal Declaration of Human Rights states that "everyone has the right to the protection of the moral and material

\footnotetext{
3 A. Burdese, Manuale di Diritto Privato Romano, UTET, Padova 2013, p. 297.

${ }^{4}$ A. Trabucchi, Istituzioni di Diritto Civile, Padova 2019, p. 628 ss.

5 Ibidem.

${ }^{6}$ A. Ottolia, The Public Interest and Intellectual Property Models, Torino 2010.
} 
interests resulting from any scientific, literary or artistic production of which he is the author".

As far as European Law is concerned, it should be borne in mind that the European Convention on Human Rights does not address the issue of the protection of intellectual property rights. Nonetheless, the European Court of Human Rights held that Article 1 of the Additional Protocol n. 1, which establishes the protection of property, also refers to intellectual property ${ }^{7}$. The legally protected interest appears to be, in the Court's thought, a legitimate expectation of gain ${ }^{8}$.

Moreover, it should be noted that Article 17 par. 2 of the Charter of Fundamental Rights of the European Union states that "intellectual property is protected", without specifying how, why and how much. In Doctrine it was considered that this rule demonstrates the acceptance of the proprietary (naturalistic) conception against the functionalistic one ${ }^{9}$.

Coming to domestic Law, it is important to note that some states do not protect intellectual property rights at the constitutional level at all. Italy, for example, does not have a constitutional provision that directly refers to copyright, trademarks or patents. The Italian Doctrine and Jurisprudence have frequently included these rights under the constitutional protection provided by Article 42 of the Constitution, which deals with "property", as well as under the protection of private economic initiative outlined in Article 41.

Finally, it should be considered that the Italian Court of Cassation's attitude towards intellectual property protection aligns with the principle expressed in Article 15 par. 1 letter c) of the International Covenant on Economic, Social and Cultural Rights: in a case dealing with the protection of copyright ${ }^{10}$, the Court of Cassation stated that this right must be referred to art works of a creative nature produced through the different forms in which artistic expression develops, and which cannot be reduced to a mere right to compensation.

The considerations made in this paragraph lead to the conclusion that the provision which best captures the topics under discussion is Article 15 of the International Covenant on Economic, Social and Cultural Rights; thus, it will be given closer attention in the next paragraphs.

7 Judgment of the European Court of Human Rights, Grande Chambre, 11 Jan. 2007, Anheuser-Busch Inc. v. Portugal (Appl. N. 73049/01).

${ }^{8}$ M. Libertini, Tutela e promozione delle creazioni intellettuali e limiti funzionali della proprietà intellettuale, [in:] AIDA, fasc.1, 2014, p. 299.

9 A. Ottolia, op.cit.

${ }_{10}$ Judgment of the Italian Court of Cassation Civil Division 23.03.1995, n. 108; Massimario, n. 0021543. 
Maria Jelda Doria

\section{THE COMPLEX RELATIONSHIP BETWEEN THE FREEDOM OF THE ARTS AND SCIENCES AND INTELLECTUAL PROPERTY PROTECTION}

Article 15 of the International Covenant on Economic, Social and Cultural Rights lays down the principles that must be followed by the States in the enactment of specific rules designed to protect an intellectual property right. Specifically, par. 2 states that "the steps to be taken by the States Parties to the present Covenant to achieve the full realization of this right shall include those necessary for the conservation, the development and the diffusion of science and culture", and par. 3 states that "the States Parties to the present Covenant undertake to respect the freedom indispensable for scientific research and creative activity".

The latter provision is incredibly bright in that it defines freedom as essential to intellectual property protection, assuming that if there is no free scientific, artistic or cultural activity, there is also no one who can benefit from it.

Article 15 also reveals that the protection of intellectual property is not riskless: if uncontrolled, it may result in the compression of the freedom of arts and sciences as well as of the individual right to freely access cultural and scientific achievements.

Thus, it can be inferred that the relationship between the freedom of arts and sciences and intellectual property protection inevitably leads to a paradox: intellectual property rights rely on the freedom of arts and scientific research, since in order to achieve a given invention one needs freedom; however, to protect and exploit intellectual property, it is necessary to limit this freedom by creating exclusive regimes. In short, intellectual property regimes protect, but at the same time limit artistic development and scientific research because by recognizing an exclusive right for the individual, the possibility of others to freely access the invention or the commercial result of the same is excluded ${ }^{11}$.

Each country uses different solutions to resolve the issue, and it is therefore necessary to work according to a comparative method to identify the limits to intellectual property protection. From a practical standpoint, these balancing differences can lead companies to settle in the state in which intellectual property rights are interpreted more widely, thus making the issue interesting also for the economic impacts it has ${ }^{12}$.

${ }^{11}$ C. Colombo, Proprietà intellettuale e libertà di ricerca scientifica: una relazione complessa-seconda parte, [in:] Ass. Luca Coscioni 27.02.2014.

12 Ibidem. 


\section{CONCRETE CASES ON THE BALANCE BETWEEN INTELLECTUAL PROPERTY PROTECTION AND THE FREEDOM OF THE ARTS AND SCIENCES}

Within the Italian Legal System, Judgment n. 108/1995 of the Court of Cassation ${ }^{13}$ is a milestone on the balance between copyright protection and the freedom of the arts encompassed in the Italian Constitution. In a case regarding the copyright protection of music works, the Court held: "The protection of copyright - to refer to creative works of art produced through the different forms in which artistic expression develops, and which cannot be reduced to a mere right to compensation - acquires a prominent importance with respect to the rights of others subjects who, in turn, deserve adequate protection in a correct balance of interests. In this case, legitimately the L. n. 633 of 1941 recognizes to the author the exclusive right to rent the musical work and the copies in which it is reproduced to third parties, precluding buyers of 'compact discs' (or similar supports) from renting them to third parties without the consent of the author. This discipline responds, in fact, to a non-unreasonable balance of interests, in accordance with the requirements of the protection of "intellectual property" (Articles 33, 35 and 42 of the Constitution), positively aimed at encouraging artistic, literary and scientific production, as well as promote the full development of human personality (Art. 3 of the Constitution) and promote the development of culture (Art. 9 of the Constitution); without, however, that the freedom of economic initiative of other people (producers, retailers, renters) is sacrificed, nor the general diffusion and use of musical works (thanks also to the impressive radio and television and concert development)".

The two terms of the balance of interests carried out by the Court of Cassation are, on the one side, the protection of intellectual property and, on the other side, the freedom of economic initiative and the general diffusion and use of musical works. It is essential to note that, in the Court of Cassation's interpretation, the protection of intellectual property - in the lack of a specific constitutional provision - has its roots in the constitutional provisions regarding the freedom of arts and sciences (Article 33), the protection of labor rights (Article 35), and the protection of private property (Article 42) and is aimed at promoting the full development of human personality (Article 3 ) and culture (Article 9).

In the Court's view, these interests are eligible to obtain a full protection through the establishment of an intellectual property right, provided that the free-

13 Judgment of the Italian Court of Cassation Civil Division 23.03.1995, n. 108; Massimario, n. 0021543. 
dom of economic initiative and the general diffusion and use of musical works are not sacrificed.

As anticipated, a concrete example from the US Legal System will be examined in this paragraph. The US Supreme Court's decision in "Association for Molecular Pathology et al. v. Myriad Genetics Inc. et al. case" (thereafter, "Myriad Case") is a critically important ruling on the balance between patent protection and the freedom of sciences.

The issue concerns a patent owned by Myriad Genetics, a start-up from the University of Utah which had identified two genes, whose mutation is indicative of a high propensity of women to contract breast cancer. Myriad Genetics registered a series of patents, in particular one in which the exact position of that gene into the DNA was concretely identified. As long as it was considered valid, it granted Myriad a monopoly on that part of the DNA, since it allowed this company to exclusively develop the test that allowed women to understand their propensity to contract breast cancer. Due to this limitation, the American Molecular Pathologists Association, which promotes the freedom of research for patients in the specific field of molecular medicine, starting from the case of a doctor who was prohibited from using a test that referred to that part of the DNA, took a legal action for nullity of the indicated patent. Five different decisions with conflicting contents alternated overtime on this controversial issue. Following the last appeal, the matter reached the US Supreme Court, which was asked (by the petitioners) to address the legal question of whether a naturally occurring segment of DNA is patentable under Section 101 of the Patent Act ${ }^{14}$ by virtue of its isolation from the rest of the human genome. The Supreme Court also addressed the patent eligibility of synthetically created DNA known as complementary DNA (cDNA), which contains the same protein-coding information found in a segment of natural DNA but omits portions within the DNA segment that do not code for proteins.

Justice Thomas, in his Opinion, stated that the Supreme Court "long held that this provision [section 101 of the Patent Act] contains an important implicit exception: Laws of nature, natural phenomena, and abstract ideas are not patentable ${ }^{15}$. Rather, they are the basic tools of scientific and technological work that lie beyond the domain of patent protection. Without this exception, there would be considerable danger that the grant of patents would tie up the use of such

1435 U.S. Code $§ 101$. Inventions patentable: Whoever invents or discovers any new and useful process, machine, manufacture, or composition of matter, or any new and useful improvement thereof, may obtain a patent therefor, subject to the conditions and requirements of this title.

${ }_{15}$ Principle expressed in Mayo, 566 U.S. 
tools and thereby inhibit future innovation premised upon them. This would be at odds with the very point of patents, which exists to promote creation. ${ }^{16}$ The rule against patents on naturally occurring things is not without limits, however, for all inventions at some level embody use, reflect, rest upon, or apply laws of nature, natural phenomena or abstract ideas and too broad an interpretation of this exclusionary principle could eviscerate patent law. As we have recognized before, patent protection strikes a delicate balance between creating incentives that lead to creation, invention and discovery and impeding the flow of information that might permit, indeed spur, invention".

The Supreme Court stated that, in this case, Myriad did not create anything, since it found an important and useful gene, and separating that gene from its surrounding genetic material is not an act of invention.

As far as cDNA is concerned, the Court stated that the creation of a cDNA sequence from mRNA results in an exons-only molecule that is not naturally occurring. In other words, cDNA retains the naturally occurring exons of DNA, but it is distinct from the DNA from which it was derived. As a result, the Court stated that "cDNA is not a product of nature and is patent-eligible under $\$ 101$ ".

In conclusion, the Supreme Court held that "a naturally occurring DNA segment is a product of nature and not patent eligible merely because it has been isolated, but that cDNA is patent eligible because it is not naturally occurring" and, therefore, it affirmed in part and reversed in part the decision of the Court of Appeals.

The US Supreme Court's decision in Myriad Genetics helped to delineate the boundaries between those products of inquiry that are "unearthed in their natural form" and those that are "the result of human innovation and creation", and gave a clearer idea of which ideas can merely be lauded for their public good and which can also be pursued for private gain ${ }^{17}$.

\section{SUMMARY}

The freedom of arts and sciences is encompassed in International, European and Italian Law. However, it should be noted that, on the one hand, Article 15 of the International Covenant on Economic, Social and Cultural Rights and Article 27 of the Universal Declaration of Human Rights are primarily concerned with the protection of the individual right to take part to cultural and scientific activity

\footnotetext{
16 Principle expressed in Diamond v. Chakrabarty, 447 U.S.

17 AMA Journal of Ethics 2015; 17(9), pp. 849-853.
} 
and to benefit from its development, along with its balance with the individual right to benefit from one's inventions or creations, and, on the other hand, $\mathrm{Eu}-$ ropean and Italian Law are primarily concerned with the establishment of the freedom itself and with its potential limitations.

The issue of intellectual property protection is not directly addressed in the Constitution of many states (such as Italy). The most relevant provisions in this regard are Article 15 of the International Covenant on Economic, Social and Cultural Rights and Article 27 of the Universal Declaration of Human Rights, which deal with the protection of both the moral and the material interests resulting from any scientific, literary or artistic production, as well as the relationships between the former and the indispensable freedom of arts and sciences.

These provisions underlay a puzzling paradox: intellectual property regimes protect, but at the same time limit scientific research because by recognizing an exclusive right for the individual, the possibility of others to freely access the invention or the commercial result of the same is excluded.

Judgment n. 108/1995 of the Italian Court of Cassation and the US Supreme Court decision on the Myriad Case represent two valuable solutions in the field of arts and sciences respectively.

\section{BIBLIOGRAPHY:}

Burdese A., Manuale di Diritto Privato Romano, Padova 2013.

Colombo C., Proprietà intellettuale e libertà di ricerca scientifica: una relazione complessa-seconda parte, [in:] Ass. Luca Coscioni 27.2.2014.

Libertini M., Tutela e promozione delle creazioni intellettuali e limiti funzionali della proprietà intellettuale, [in:] AIDA, fasc.1, 2014.

Ottolia A., The Public Interest and Intellectual Property Models, Torino 2010.

Santosuosso A., Proprietà intellettuale e libertà di ricerca scientifica: una relazione complessa, [in:] Ass. Coscioni 13.3.2014.

Trabucchi A., Istituzioni di Diritto Civile, Padova 2019.

AMA Journal of Ethics 2015;17(9):849-853. 